\title{
Analysis of Thermophilic Clades within the Genus Streptomyces by 16S Ribosomal DNA Sequence Comparisons
}

\author{
DAEJIN KIM,,${ }^{1,2}$ JONGSIK CHUN, ${ }^{1,2}$ NEVZAT SAHIN,${ }^{2,3}$ YUNG CHIL HAH, ${ }^{1}$ AND MICHAEL GOODFELLOW ${ }^{2 *}$ \\ Department of Microbiology and Research Center for Molecular Microbiology, Seoul National University, Seoul 151-742, \\ Republic of Korea ${ }^{1}$; Department of Microbiology, The Medical School, Newcastle upon Tyne, NE2 4HH, United \\ Kingdom ${ }^{2}$; and O.M.Ü. Egitim Fakültesi, Biyoloji Bölümü, 55200 Atakum-Samsun 55200, Turkey ${ }^{3}$
}

\begin{abstract}
Almost complete sequences of the 16S rRNA genes of eight representative thermophilic streptomycetes were determined following the isolation and cloning of the amplified genes. These sequences were aligned with those of representative mesophilic streptomycetes, and phylogenetic trees were inferred by using four tree-making algorithms. The thermophilic streptomycetes formed two distinct clades that were supported by high bootstrap values based on 1,000 resamplings. One clade encompassed Streptomyces macrosporus and related species, and the second clade included Streptomyces thermodiastaticus and allied taxa. The relationships between the organisms were not markedly influenced by the different tree-making methods, but the rooting of the tree was sensitive to the choice of the outgroup strain. It is evident from this study that the thermophilic streptomycetes do not merit recognition as a distinct taxon within the genus Streptomyces.
\end{abstract}

Most of the emphasis in streptomycete systematics has been focused on mesophilic strains, which grow at temperatures between 15 and $37^{\circ} \mathrm{C}$ and have optimum temperatures around $25^{\circ} \mathrm{C}$. Thermophilic streptomycetes have growth temperature ranges between 28 and $55^{\circ} \mathrm{C}$, although cultures of "Streptomyces thermofuscus" and "Streptomyces thermophilus" have been reported to grow at $65^{\circ} \mathrm{C}(45)$. There is some controversy about whether streptomycetes that grow at $45^{\circ} \mathrm{C}$ or above should be assigned to distinct taxa or should be considered thermotolerant variants of mesophilic species. Craveri and Pagani (6) proposed the subgenus Thermostreptomyces for thermophilic strains, but other workers $(5,21)$ have considered such organisms thermotolerant rather than thermophilic streptomycetes. The name Thermostreptomyces was listed under genera incertae sedis in Bergey's Manual of Determinative Bacteriology, 8th ed. (33).

The only comprehensive taxonomic study of thermophilic streptomycetes was carried out by Goodfellow et al. (12), who examined 50 thermophilic, neutrophilic streptomycetes isolated from diverse habitats and representative mesophilic marker strains that had been included in the extensive numerical taxonomic survey of Williams et al. (48). The test strains were screened for 135 unit characters, and the resultant data were analyzed by using three resemblance coefficients and an average-linkage algorithm. In all three analyses, the thermophilic streptomycetes formed a distinct aggregate taxon that encompassed three major clusters ( 7 to 19 strains), five minor clusters ( 2 to 3 strains), and two single-member clusters.

The three major clusters were equated with Streptomyces megasporus, Streptomyces thermoviolaceus, and Streptomyces thermovulgaris, and one of the minor clusters was equated with Streptomyces macrosporus. The name Streptomyces thermolineatus was proposed for one of the remaining minor clusters. Emended descriptions were given for Streptomyces macrosporus (Krassilnikov et al. 1968) Agre 1983 (1, 20), Streptomyces thermoviolaceus Henssen 1957 (13), and Streptomyces thermovulgaris Henssen 1957 (13). It was also proposed that the name Streptomyces macrosporus Krassilnikov et al. 1968 should be revived. The mesophilic streptomycetes were recovered in the

\footnotetext{
* Corresponding author. Mailing address: Department of Microbiology, The Medical School, Framlington Place, Newcastle upon Tyne, NE2 4HH, United Kingdom. Fax: 44-91-222-7736.
}

major and minor clusters recognized by Williams et al. (48), and, with the exception of the Streptomyces albus strains, they formed a second aggregate group.

Molecular systematic methods, notably the methods used to determine taxonomic relationships on the basis of nucleic acid sequence and DNA-DNA relatedness data (36), are having an increasingly important impact on streptomycete systematics (31, $37,38,40,46,49)$. In this investigation, the almost complete sequences of the $16 \mathrm{~S}$ rRNA genes (rDNAs) of representative thermophilic streptomycetes were determined and compared, by using several algorithms $(14,18,23)$, with corresponding sequences of mesophilic streptomycetes held in the public domain in order to further clarify the taxonomy of organisms classified in the genus Streptomyces.

\section{MATERIALS AND METHODS}

Organisms and culture conditions. Cultures of the test strains (Table 1) were grown on modified Bennett's agar plates $(15)$ at $45^{\circ} \mathrm{C}$ for 3 days. After incubation, biomass was scraped from the plates and washed twice with T.E. buffer $(\mathrm{pH}$ 8) (35). The streptomycetes were maintained on modified Bennett's agar slopes and as glycerol suspensions $(20 \%, \mathrm{vol} / \mathrm{vol})$ at $-20^{\circ} \mathrm{C}$.

DNA extraction. Chromosomal DNA was isolated by using a procedure (4) slightly modified from that of Pitcher et al. (32).

PCR amplification of $16 S$ rDNA. The $16 \mathrm{~S}$ rDNAs were enzymatically amplified by using two universal primers, p27f and p1525r (22), and then further purified by using an Ultrafree-MC filter unit (pore size, $0.45 \mu \mathrm{m}$; Millipore, Ltd., Watford, England) and the protocol recommended by the manufacturer. The PCR procedure which we used has been described previously (4).

Isolation and cloning of amplified 16S rDNA. Purified 16S rDNA fragments were ligated into the pGEM-T vector (Promega Co., Southampton, England) by following the manufacturer's instructions. Ligated plasmids were then transformed into Escherichia coli JM109, and transformants were selected on the basis of the results of the blue-white screening procedure (35).

Sequencing of $16 \mathrm{~S}$ rDNA. Plasmids containing the $16 \mathrm{~S}$ rDNA fragment were isolated by using the standard purification method recommended by the manufacturer (Promega Co.). Purified plasmids were sequenced by using a Taq DyeDeoxy terminator cycle sequencing kit (Applied Biosystems, Foster City, Calif.). Sequencing gel electrophoresis was carried out and nucleotide sequences were automatically obtained by using an Applied Biosystems model 373A DNA sequencer and software provided by the manufacturer. The oligonucleotide primers used in the sequencing reaction have been described previously (4)

Phylogenetic analysis. The 16S rDNA sequences obtained were aligned manually with streptomycete nucleotide sequences (Table 1) obtained from the Ribosomal Database Project (24) and EMBL-GenBank databases. Two data sets were generated and analyzed separately as some of the nucleotide sequences obtained from the databases were partial sequences (that is, they consisted of less than 1,300 nucleotides). The first data set included sequences containing more than 1,300 nucleotides, and the second data set consisted of partial sequences 
TABLE 1. Strains used and their nucleotide sequence accession numbers

\begin{tabular}{|c|c|c|c|c|}
\hline Species or subspecies & Strain $^{a}$ & Source $^{b}$ & $\begin{array}{c}\text { Accession } \\
\text { no. }\end{array}$ & Reference \\
\hline \multicolumn{5}{|c|}{ Organisms whose complete sequences ( $>1,300$ nucleotides) were used } \\
\hline Kitasatosporia griseola & & DSM $43859^{\mathrm{T}}$ & M55221 & 46 \\
\hline Kitasatosporia phosalacinea & & DSM $43860^{\mathrm{T}}$ & M55223 & 46 \\
\hline Kitasatosporia setae & & DSM $43861^{\mathrm{T}}$ & M55220 & 46 \\
\hline Streptomyces ambofaciens & ISP $5053^{\mathrm{T}}$ & ATCC $23877^{\mathrm{T}}$ & M27245 & 31 \\
\hline Streptomyces bikiniensis & ISP $5581^{\mathrm{T}}$ & DSM $40581^{\mathrm{T}}$ & X79851 & 25 \\
\hline Streptomyces bluensis & ISP $5564^{\mathrm{T}}$ & & X79324 & 25 \\
\hline Streptomyces caelestis & ISP 5084 & NRRL $2418^{\mathrm{T}}$ & X80824 & 25 \\
\hline Streptomyces violaceoruber (Streptomyces coelicolor) & & $\mathrm{A} 3(2)$ & X60514 & 40 \\
\hline "Streptomyces espinosus" & & NRRL 5729 & $\mathrm{X} 80826$ & 25 \\
\hline Streptomyces galbus & ISP $5089^{\mathrm{T}}$ & DSM $40089^{\mathrm{T}}$ & X79852 & 25 \\
\hline Streptomyces glaucescens & & DSM 40716 & X79322 & 25 \\
\hline Streptomyces griseus subsp. griseus & ISP $5236^{\mathrm{T}}$ & KCTC $9080^{\mathrm{T}}$ & X61478 & 17 \\
\hline "Streptomyces hygroscopicus subsp. limoneus" & & ATCC 21431 & X79853 & 25 \\
\hline Streptomyces lincolnensis & ISP $5355^{\mathrm{T}}$ & NRRL $2936^{\mathrm{T}}$ & X79854 & 25 \\
\hline "Streptomyces ornatus" & ISP $5307^{\mathrm{T}}$ & DSM $40307^{\mathrm{T}}$ & X79326 & 25 \\
\hline Streptomyces pseudogriseolus & & NRRL 3985 & X80827 & 25 \\
\hline Streptomyces subrutilus & ISP $5445^{\mathrm{T}}$ & DSM $40445^{\mathrm{T}}$ & $\mathrm{X} 80825$ & 25 \\
\hline Streptomyces mashuensis & ISP $5221^{\mathrm{T}}$ & DSM $40221^{\mathrm{T}}$ & X79323 & 25 \\
\hline Streptomyces thermodiastaticus & ISP $5573^{\mathrm{T}}$ & DSM $40573^{\mathrm{T}}$ & Z68101 & This study \\
\hline Streptomyces thermolineatus & & DSM $41451^{\mathrm{T}}$ & Z68097 & This study \\
\hline Streptomyces megasporus & & DSM $41476^{\mathrm{T}}$ & Z68100 & This study \\
\hline Streptomyces macrosporus & & DSM $41449^{\mathrm{T}}$ & Z68099 & This study \\
\hline Streptomyces thermonitrificans & ISP $5579^{\mathrm{T}}$ & DSM $40579^{\mathrm{T}}$ & Z68098 & This study \\
\hline Streptomyces thermovulgaris & ISP $5444^{\mathrm{T}}$ & DSM $40444^{\mathrm{T}}$ & Z68094 & This stud \\
\hline Streptomyces thermoviolaceus subsp. apingens & & DSM $41392^{\mathrm{T}}$ & Z68095 & This study \\
\hline Streptomyces thermoviolaceus subsp. thermoviolaceus & ISP $5443^{\mathrm{T}}$ & DSM $40443^{\mathrm{T}}$ & Z68096 & This study \\
\hline \multicolumn{5}{|c|}{ Organisms whose partial sequences $(<1,300$ nucleotides) were used } \\
\hline Streptomyces albus & ISP $5313^{\mathrm{T}}$ & DSM $40313^{\mathrm{T}}$ & $\mathrm{X} 53163$ & 37 \\
\hline Streptomyces brasiliensis & & DSM $43159^{\mathrm{T}}$ & X53162 & 37 \\
\hline Streptomyces diastaticus & ISP $5496^{\mathrm{T}}$ & DSM $40496^{\mathrm{T}}$ & $\mathrm{X} 53161$ & 37 \\
\hline Streptomyces lavendulae & ISP $5069^{\mathrm{T}}$ & DSM $2014^{\mathrm{T}}$ & X53173 & 37 \\
\hline Streptomyces purpureus & & DSM $43460^{\mathrm{T}}$ & $\mathrm{X} 53170$ & 37 \\
\hline Streptomyces abikoensis & & DSM $40831^{\mathrm{T}}$ & X53168 & 37 \\
\hline Streptomyces baldacii & & DPDU $0819^{T}$ & X53164 & 37 \\
\hline "Streptomyces cinnamoneus subsp. azocolutum" & & DPDU $0074^{\mathrm{T}}$ & $\mathrm{X} 53165$ & 37 \\
\hline Streptomyces cinnamoneus subsp. cinnamoneus & ISP $5005^{\mathrm{T}}$ & DPDU $0093^{\mathrm{T}}$ & $\mathrm{X} 53171$ & 37 \\
\hline Streptomyces ladakanum & ISP $5587^{\mathrm{T}}$ & DSM $40587^{\mathrm{T}}$ & X53167 & 37 \\
\hline Streptomyces luteoreticuli & ISP 5509 & ATCC 27446 & X53172 & 37 \\
\hline Streptomyces olivoreticuli subsp. cellulophilus & & DPDU $0278^{\mathrm{T}}$ & X53166 & 37 \\
\hline Streptomyces salmonis & & DPDU $00098^{\mathrm{T}}$ & X53169 & 37 \\
\hline
\end{tabular}

${ }^{a}$ ISP, International Streptomyces project.

${ }^{b}$ ATCC, American Type Culture Collection, Rockville, Md.; DPDU, Instituto di difesa delle Plante, Universita degli Studi di Udine, Udine, Italy; DSM, Deutsche Sammlung von Mikroorganismen und Zellkulturen $\mathrm{GmbH}$, Braunschweig, Germany; KCTC, Korean Collection of Type Cultures, Korean Research Institute of Bioscience and Biotechnology, Taejeon, Republic of Korea; NRRL, Northern Regional Research Laboratory, Agricultural Research Service, U.S. Department of Agriculture, Peoria, Ill.

(Table 1). Data set 1 contained information on 1,438 positions for 26 streptomycetes, and data set 2 contained information on 1,028 nucleotide positions for 39 streptomycetes.

Evolutionary trees for the two data sets were inferred by using the following four algorithms: the neighbor-joining (34), least-squares (11), maximum-parsimony (19), and maximum-likelihood (8) methods. Evolutionary distance matrices for the neighbor-joining and least-squares methods were generated as described by Jukes and Cantor (16). The PHYLIP package (10) was used for the neighbor-joining, Fitch-Margoliash, and maximum-parsimony analyses, and the fastDNAml program (29) was used for the maximum-likelihood method. The resultant unrooted tree topologies were evaluated by performing bootstrap analyses (9) of the neighbor-joining method data based on 1,000 resamplings. The root positions of the unrooted trees were estimated by using the neighbor-joining method and five outgroup organisms (Arthrobacter globiformis DSM $20214^{\mathrm{T}}$ [T = type strain] [accession number M23411], Bacillus subtilis [K00637], E. coli [J01695], Nocardia asteroides ATCC $19247^{\mathrm{T}}$ [Z36934], and Streptosporangium roseum DSM 43021 ${ }^{\mathrm{T}}$ [X70425]) as described by Swofford and Olsen (39).

\section{RESULTS AND DISCUSSION}

The almost complete $16 \mathrm{~S}$ rDNA sequences $(1,481$ to 1,490 nucleotides between $E$. coli positions 28 and 1524 [3]) obtained for eight representative thermophilic streptomycetes were compared with the corresponding sequences of 18 mesophilic streptomycetes (including Kitasatosporia strains) by using four tree-making algorithms. It is evident from the phylogenetic tree and the sequence similarity values (Table 2) that the thermophilic streptomycetes formed two phyletic lines (Fig. 1). The taxonomic integrity of the two clades was supported by relatively high bootstrap values based on 1,000 resamplings. The integrity of the phyletic line consisting of Streptomyces macrosporus and related taxa was supported by the results obtained with all four algorithms (i.e., the neighbor-joining, least-squares, maximum-parsimony, and maximum-likelihood methods). The phyletic line that included Streptomyces thermodiastaticus and related taxa was also recovered in all four analyses. The two phyletic lines were consistently recovered in analyses based on the partial nucleotide sequences of the 8 thermophilic and 31 mesophilic streptomycetes (Fig. 2). It is evident from these data that the thermophilic streptomycetes 


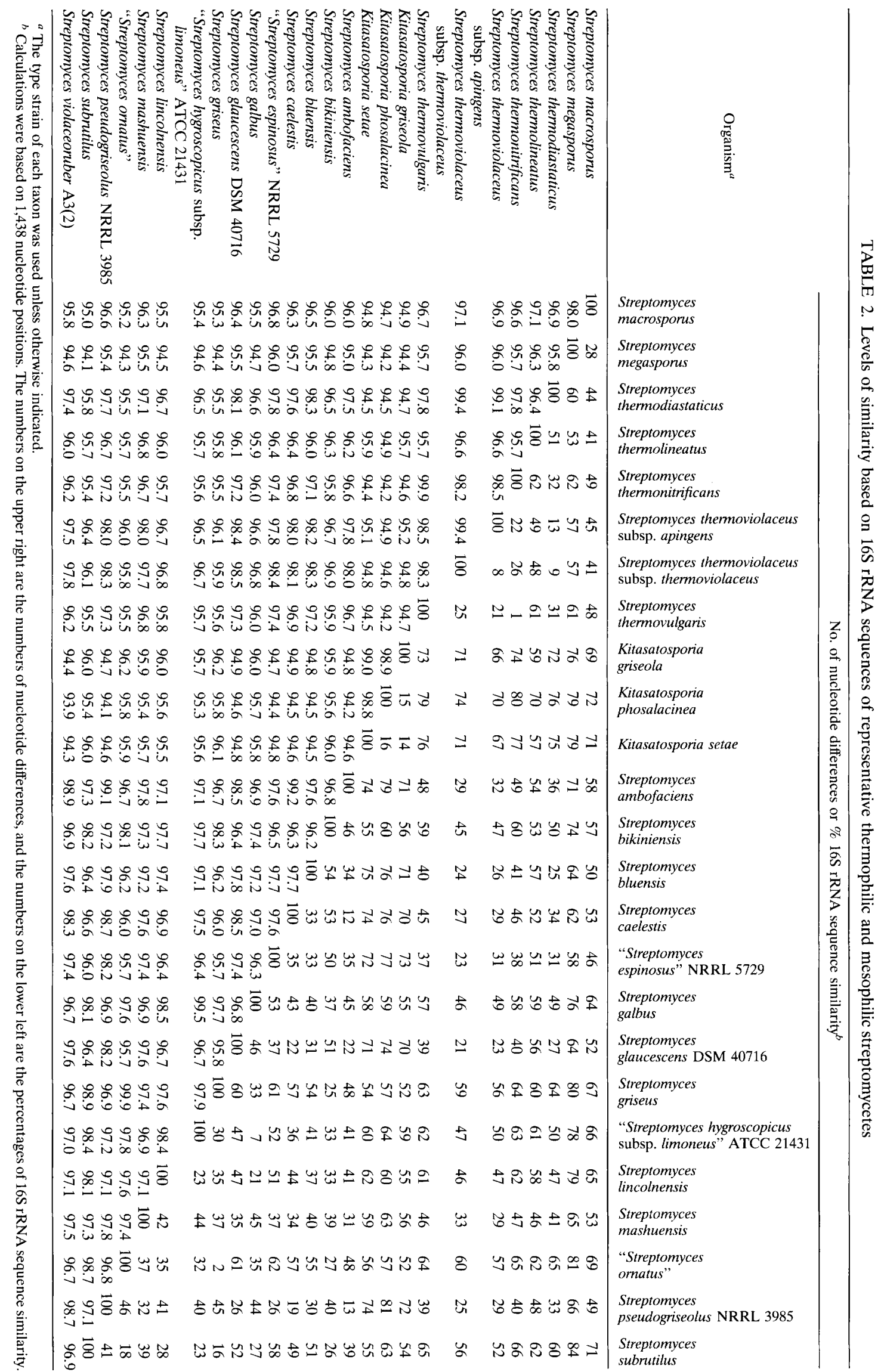




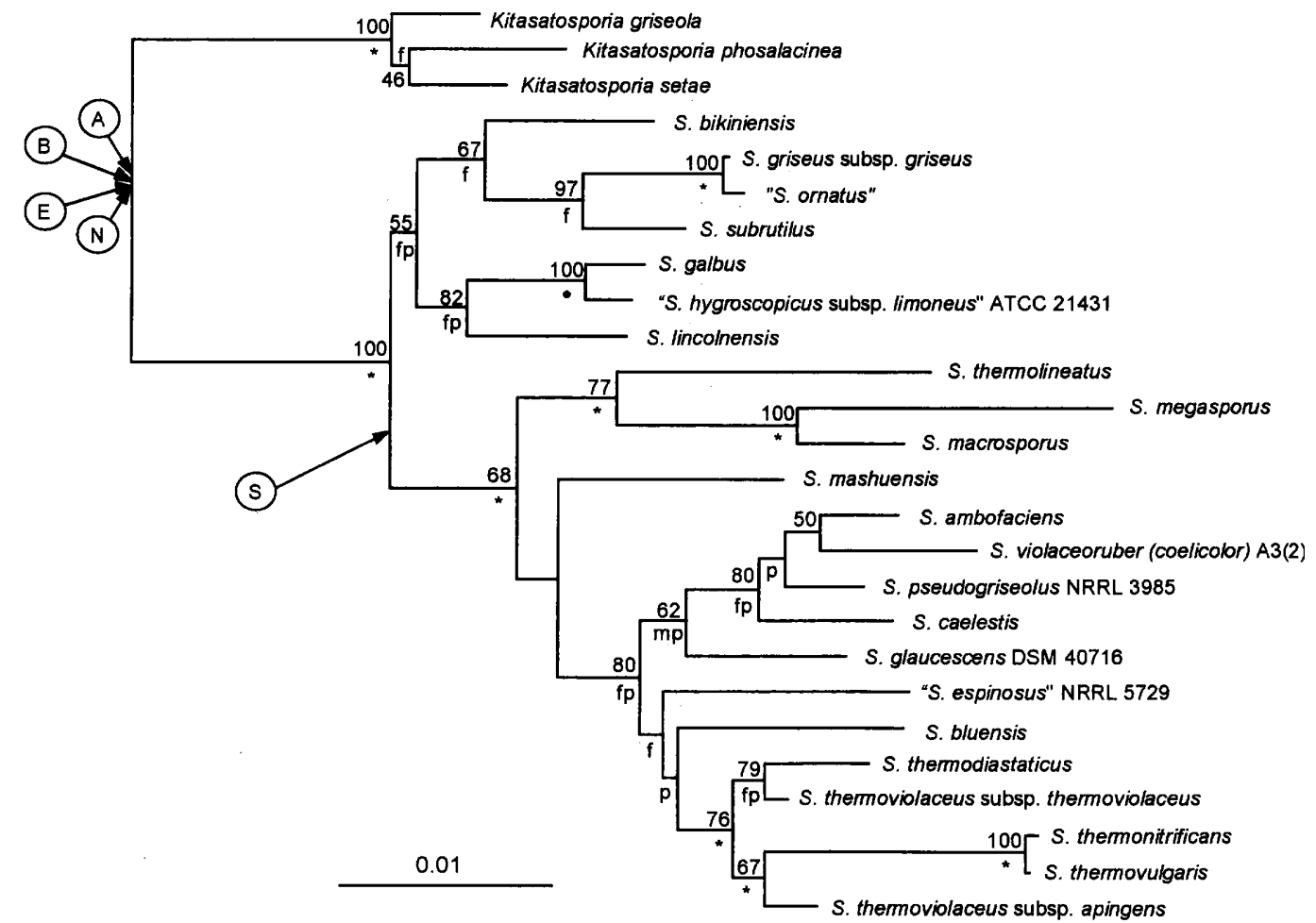

FIG. 1. Neighbor-joining tree (34) based on nearly complete $16 \mathrm{~S}$ rRNA sequences of 26 streptomycetes. $\mathrm{f}, \mathrm{p}$, and $\mathrm{m}$ indicate branches that were also found when we used the Fitch-Margoliash (11), maximum-parsimony (19), and maximum-likelihood methods (8), respectively; the asterisks indicate branches that were recovered with all four methods. The numbers at the nodes indicate the levels of bootstrap support based on a neighbor-joining analysis of 1,000 resampled data sets; only values that are more than $40 \%$ are given. The estimated positions of the root organisms are indicated by the circled letters, as follows: A, A. globiformis; B, B. subtilis; E, E. coli; $\mathrm{N}, N$. asteroides; S, Streptosporangium roseum. The test strains were type cultures unless otherwise indicated.

should not be assigned to a distinct subgenus within the genus Streptomyces as proposed by Craveri and Pagani (6).

The average nucleotide sequence similarity value obtained when the Streptomyces macrosporus, Streptomyces megasporus, and Streptomyces thermolineatus strains were compared was $97.1 \% \pm 0.7 \%$, and the closest relationship found was the relationship between the type strains of Streptomyces macrosporus and Streptomyces megasporus (level of similarity, $98.0 \%$ ). The relatively large number of nucleotide differences found in the $16 \mathrm{~S}$ rRNA sequences of the type strains of these three species provides further support for the taxonomic integrity of these species. Members of all three species formed distinct clusters within a recognizable aggregate group in the numerical phenetic survey of Goodfellow et al. (12). The average level of similarity between members of the Streptomyces macrosporus clade and the mesophilic streptomycetes was $95.5 \% \pm 0.7 \%$. The closest relationships were the relationships between Streptomyces macrosporus DSM $41449^{\mathrm{T}}$ and "Streptomyces espinosus" NRRL 5729 (level of similarity, 96.8\%) and between Streptomyces thermolineatus DSM $41451^{\mathrm{T}}$ and Streptomyces mashuensis DSM 40221 ${ }^{\mathrm{T}}$ (level of similarity, 96.8\%). The Streptomyces macrosporus clade was also well separated from the mesophilic streptomycetes as determined by the broader analysis based on partial nucleotide sequences.

The second phyletic line included the type strains of Streptomyces thermodiastaticus, Streptomyces thermolineatus, Streptomyces thermoviolaceus subsp. apingens, Streptomyces thermoviolaceus subsp. thermoviolaceus, and Streptomyces thermovulgaris. The average level of nucleotide similarity found for these strains was high $(98.7 \% \pm 0.7 \%)$. The highest level of similar- ity was the level of similarity between the Streptomyces thermonitrificans and Streptomyces thermovulgaris strains $(99.9 \%)$. This result is consistent with the proposal of Williams et al. (48) that Streptomyces thermonitrificans Desai and Dhala 1967 (7) should become a subjective synonym of Streptomyces thermovulgaris Henssen 1957 (13). However, on the basis of phenotypic properties, Goodfellow et al. (12) concluded that Streptomyces thermonitrificans should be reduced to a synonym of Streptomyces thermoviolaceus Henssen 1957 (13) emend. Goodfellow et al. 1987 (12). AT-L30 ribosomal protein analyses also revealed that Streptomyces thermonitrificans, Streptomyces thermoviolaceus, and Streptomyces thermovulgaris are closely related (27). DNA-DNA relatedness studies are needed to resolve the finer taxonomic relationships among Streptomyces thermonitrificans, Streptomyces thermoviolaceus, and Streptomyces thermovulgaris.

The type strains of Streptomyces thermoviolaceus subsp. apingens and Streptomyces thermoviolaceus subsp. thermoviolaceus did not show monophyly even though they were closely related in terms of nucleotide sequence similarity (level of similarity, 99.4\%). This result can be attributed to the tree-making algorithms which considered the close relationships between Streptomyces thermoviolaceus subsp. thermoviolaceus and Streptomyces thermodiastaticus (level of similarity, 99.4\%) and between Streptomyces thermoviolaceus subsp. apingens and Streptomyces thermonitrificans or Streptomyces thermovulgaris (level of similarity, 98.5\%). Clearly, representatives of these taxa should be included in DNA-DNA pairing studies. The average level of similarity between members of the Streptomyces macrosporus and Streptomyces thermodiastaticus clades was $96.3 \% \pm 0.5 \%$. 


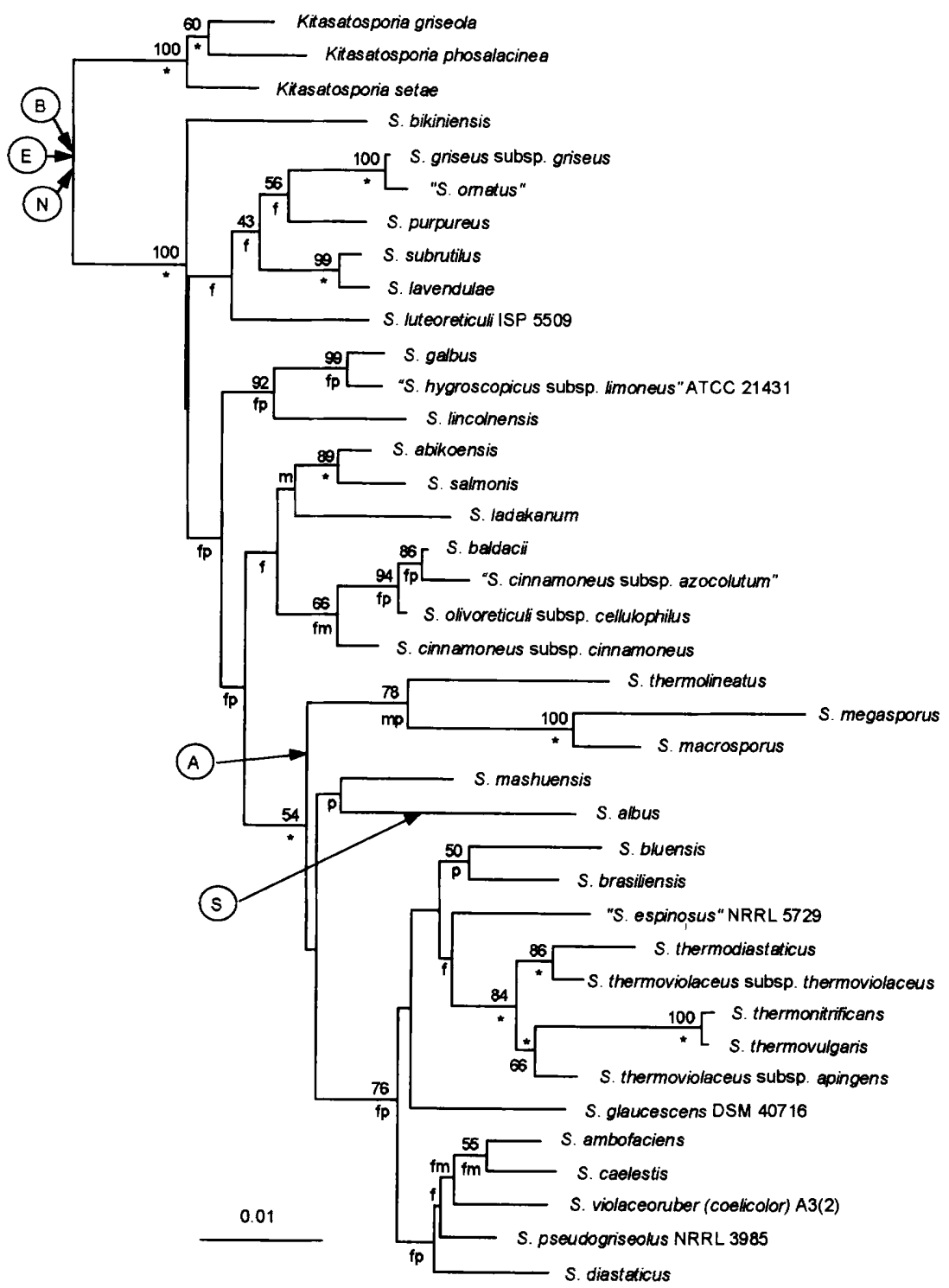

FIG. 2. Phylogenetic tree based on partial 16S rRNA sequences of 39 Streptomyces strains. For details see the legend to Fig. 1.

The $\mathrm{G}+\mathrm{C}$ contents of the $16 \mathrm{~S}$ rDNAs of the eight thermophilic streptomycetes were $60.05 \pm 0.63 \mathrm{~mol} \%$, and the corresponding value for the 15 mesophilic strains was $58.83 \pm 0.61$ mol\%; the differences between these two sets of data were too small to affect the outcome of the phylogenetic analyses. Members of the Streptomyces thermodiastaticus clade showed a closer relationship to some of the mesophilic streptomycetes than to Streptomyces macrosporus and related strains (Table 2; Fig. 1). Particularly high levels of nucleotide similarity were found between Streptomyces thermodiastaticus DSM $40573^{\mathrm{T}}$ and Streptomyces bluensis ISP $5564^{\mathrm{T}}(98.3 \%)$, between Streptomyces thermoviolaceus subsp. apingens DSM $41392^{\mathrm{T}}$ and Streptomyces glaucescens DSM 40716 (98.4\%), and between Streptomyces thermoviolaceus subsp. thermoviolaceus DSM $40443^{\mathrm{T}}$ and Streptomyces glaucescens DSM 40716 (98.5\%). Although the relationships which we found between the members of the Streptomyces thermodiastaticus subgroup and the associated mesophilic streptomycetes were not supported by the product of the maximum-likelihood analysis, this clade was apparent in the trees based on both nearly complete (Fig. 1) and partial (Fig. 2) nucleotide sequences; the bootstrap values obtained for members of the clade were more or less similar to those found in the Streptomyces thermodiastaticus subgroup.

It is likely that Streptomyces thermodiastaticus and allied mesophilic streptomycetes form a monophyletic group. This conclusion is supported by the results of AT-L30 protein analyses, which show that Streptomyces bluensis, Streptomyces diastaticus, Streptomyces glaucescens, and Streptomyces violaceonuber A3(2) are closely related to Streptomyces thermonitrificans, Streptomyces thermoviolaceus, and Streptomyces thermovulgaris (27). Consequently, it seems likely that the close relationship proposed on the basis of phenotypic properties between Streptomyces thermodiastaticus (Bergey et al. 1923) Waksman $1953(2,41)$ and Streptomyces halstedii (Waksman and Curtis 1916) Waksman and Henrici $1948(42,44,47)$ is more apparent than real. The position of Streptomyces mashuensis DSM $40221^{\mathrm{T}}$ is equivocal (Fig. 1 and 2).

The relationships among the organisms were not markedly 
influenced by the different algorithms used to analyze the almost complete nucleotide sequences. However, the classification was affected by the nature of the outgroup strains used. The tree was rooted between the kitasatosporiae and the streptomycetes when $A$. globiformis, $B$. subtilis, $E$. coli, and $N$. asteroides strains were used as the outgroup strains (Fig. 1). However, when Streptosporangium roseum DSM $43021^{\mathrm{T}}$ was used as the outgroup strain, the root more or less bisected the tree. The position of the root in the corresponding tree based on the partial nucleotide data set was also influenced by the outgroup strain (Fig. 2). However, once again it is interesting that the kitasatosporiae were separated from the streptomycetes when the $B$. subtilis, E. coli, and $N$. asteroides strains were used as the outgroup strains. It is clear from these results that the position of the root in the Streptomyces clade cannot be estimated unequivocally.

Wellington et al. (46) proposed, mainly on the basis of $16 \mathrm{~S}$ rRNA sequence data, that the name Kitasatosporia Omura et al. 1982 (30) should be reduced to a synonym of the name Streptomyces Waksman and Henrici 1943 (43). In addition, Ochi and Hiranuma (28) found that Kitosatosporia griseola, Kitosatosporia mediocidica, Kitosatosporia phosalacinea, and Kitosatosporia setae are closely related to Streptomyces exfoliatus by using data derived from analyses of ribosomal protein AT-L30. It has also been proposed that Kitosatosporia cystarginea should be transferred to the genus Streptomyces on the basis of chemotaxonomic, physiological, and DNA-DNA relatedness data (26). Nevertheless, kitasatosporiae can be distinguished from streptomycetes because major amounts of galactose and meso-diaminopimelic acid are found in their wholeorganism hydrolysates (30). They also consistently produce submerged spores in liquid culture, a trait rare among streptomycetes.

In this investigation, the kitasatosporiae were recovered as a deeply rooted phyletic line when the first data set was analyzed with $A$. globiformis, $B$. subtilis, E. coli, and N. asteroides strains as outgroup strains (Fig. 1). The overall average level of nucleotide sequence similarity for the 16S rRNA molecules of the kitasatosporiae and mesophilic and thermophilic streptomycetes was $95.1 \% \pm 0.6 \%$. The detailed taxonomic relationships of the kitasatosporiae need to be reevaluated in light of additional molecular and chemosystematic data.

The results of this study provide further evidence of the value of $16 \mathrm{~S}$ rRNA sequencing in the circumscription of actinomycete genera and in the elucidation of the subgeneric structure of complex taxa, such as the genus Streptomyces. It is evident from our results that thermophilic streptomycetes form at least two phyletic lines which can be distinguished from clades composed of mesophilic streptomycetes.

\section{ACKNOWLEDGMENTS}

Part of this work was supported by a KOSEF (Republic of Korea) research grant to the Research Center for Molecular Microbiology. J.C. is grateful to the British Council (Seoul, Republic of Korea) for financial support and for an Overseas Research Studentship Award.

We are also indebted to the Ribosomal Database Project for access to aligned sequence data and to R. M. Kroppenstedt for providing cultures.

\section{REFERENCES}

1. Agre, N. S. 1983. Genera Streptomyces, Streptoverticillium, and Chainia, p. 52-71. In T. F. Gause, T. P. Preobrazhenskaya, M. A. Sveshnikova, L. P. Terekhova, and T. S. Maksimova (ed.), A guide for the determination of actinomycetes. Nauka, Moscow. (In Russian.)

2. Bergey, D. H., F. C. Harrison, R. S. Breed, B. W. Hammer, and F. M. Huntoon. 1923. Bergey's manual of determinative bacteriology, 1st ed. The Williams and Wilkins Co,, Baltimore.
3. Brosius, J., M. L. Palmer, P. J. Kennedy, and H. F. Noller. 1978. Complete nucleotide sequence of a $16 \mathrm{~S}$ ribosomal RNA gene from Escherichia coli. Proc. Natl. Acad. Sci. USA 75:4801-4805.

4. Chun, J., and M. Goodfellow. 1995. A phylogenetic analysis of the genus Nocardia with 16S rRNA gene sequences. Int. J. Syst. Bacteriol. 45:240-245.

5. Corbaz, R., P. H. Gregory, and M. E. Lacey. 1963. Thermophilic and mesophilic actinomycetes in mouldy hay. J. Gen. Microbiol. 32:449-456.

6. Craveri, R., and H. Pagani. 1962. Thermophilic micro-organisms among actinomycetes in the soil. Ann. Microbiol. 12:115-130.

7. Desai, A. J., and S. A. Dhala. 1967. Streptomyces thermonitrificans sp. n., a thermophilic streptomycete. Antonie Leeuwenhoek 33:137-144.

8. Felsenstein, J. 1981. Evolutionary trees from DNA sequences: a maximum likelihood approach. J. Mol. Evol. 17:368-376.

9. Felsenstein, J. 1985. Confidence limits on phylogenies: an approach using the bootstrap. Evolution 39:783 -791.

10. Felsenstein, J. 1993. PHYLIP (phylogenetic inference package), version 3.5c. Department of Genetics, University of Washington, Seattle.

11. Fitch, W. M., and E. Margoliash. 1967. Construction of phylogenetic trees: a method based on mutation distances as estimated from cytochrome $\mathrm{c}$ sequences is of general applicability. Science 155:279-284.

12. Goodfellow, M., J. Lacey, and C. Todd. 1987. Numerical classification of thermophilic streptomycetes. J. Gen. Microbiol. 133:3135-3149.

13. Henssen, A. 1957. Über die Bedeutung der thermophilen Mikroorganismen für der Zersetzung des Stallmistes. Arch. Mikrobiol. 27:63-81.

14. Huelsenbeck, J. P., and D. M. Hillis. 1993. Success of phylogenetic methods in the four-taxon case. Syst. Biol. 42:247-264.

15. Jones, K. L. 1949. Fresh isolates of actinomycetes in which the presence of sporogenous aerial mycelia is a fluctuating characteristic. J. Bacteriol. 57: 141-145.

16. Jukes, T. H., and C. R. Cantor. 1969. Evolution of protein molecules, p. 21-132. In H. N. Munro (ed.), Mammalian protein metabolism. Academic Press, New York.

17. Kim, E., H. Kim, K. H. Kang, Y. H. Kho, and Y. H. Park. 1991. Complete nucleotide sequence of a $16 \mathrm{~S}$ ribosomal RNA gene from Streptomyces grisetus subsp. griseus. Nucleic Acids Res. 19:1149.

18. Kim, J. 1993. Improving the accuracy of phylogenetic estimation by combining different methods. Syst. Biol. 42:331-340.

19. Kluge, A. G., and F. S. Farris. 1969. Quantitative phyletics and the evolution of anurans. Syst. Zool. 18:1-32.

20. Krassilnikov, N. A., N. S. Agre, L. A. Dorokhova, and A. A. Sokolov. 1968. Three new species of thermophilic actinomycetes. Mikrobiologiya 37:75-83. (In Russian.)

21. Küster, E., and R. Locci. 1963. Studies on peat and peat micro-organisms. I. Taxonomic studies on thermophilic actinomycetes isolated from peat. Arch. Mikrobiol. 45:188-197.

22. Lane, D. J. 1991. 16S/23S rRNA sequencing, p. 115-175. In E. Stackebrandt and $M$. Goodfellow (ed.), Nucleic acid techniques in bacterial systematics. John Wiley and Sons, Chichester, United Kingdom.

23. Li, W. H., and M. Gouy. 1990. Statistical tests of molecular phylogenies. Methods Enzymol. 183:645-659.

24. Maidak, B. L., N. Larsen, M. J. McCaughey, R. Overbeek, G. J. Olsen, K. Fogel, J. Blandy, and C. R. Woese. 1994. The Ribosomal Database Project. Nucleic Acids Res. 22:3485-3487.

25. Mehling, A., U. Wehmeier, and W. Piepersberg. Unpublished data.

26. Nakagaito, Y., A. Shimazu, A. Yokota, and T. Hasegawa. 1992. Proposal of Streptomyces atroaurantiacus sp. nov. and Streptomyces kifunensis sp. nov. and transferring Kitasatosporia cystarginea Kusakabe and Isono to the genus Streptomyces as Streptomyces cystargineus comb. nov. J. Gen. Appl. Microbiol. 38:627-633.

27. Ochi, K. 1995. A taxonomic study of the genus Streptomyces by analysis of ribosomal protein AT-L30. Int. J. Syst. Bacteriol. 45:507-514.

28. Ochi, K., and H. Hiranuma. 1994. A taxonomic review of the genera Kitasatosporia and Streptoverticillium by analysis of ribosomal protein AT-L30. Int. J. Syst. Bacteriol. 44:285-292.

29. Olsen, G. J., H. Matsuda, R. Hagstrom, and R. Overbeek. 1994. FastDNAml: a tool for construction of phylogenetic trees of DNA sequences using maximum likelihood. Comput. Appl. Biol. Sci. 10:41-48.

30. Omura, S., Y. Takahashi, Y. Iwai, and H. Tanaka. 1982. Kitasatosporia, a new genus of the order Actinomycetales. J. Antibiot. 35:1013-1019.

31. Pernodet, J. L., F. Boccard, M. T. Alegre, J. Gagnat, and M. Guerineau. 1989. Organization and nucleotide sequence analysis of a ribosomal RNA gene cluster from Streptomyces ambofaciens. Gene 79:33-46.

32. Pitcher, D. G., N. A. Saunders, and R. J. Owen. 1989. Rapid extraction of bacterial genomic DNA with guanidium thiocyanate. Lett. Appl. Microbiol. 8:151-156.

33. Pridham, T. G., and H. D. Tresner. 1974. Family VII. Streptomycetaceae Waksman and Henrici 1943, 339, p. 747-748. In R. E. Buchanan and N. E. Gibbons (ed.), Bergey's manual of determinative bacteriology, 8th ed. Williams and Wilkins, Baltimore

34. Saitou, N., and M. Nei. 1987. The neighbor-joining method: a new method for reconstructing phylogenetic trees. Mol. Biol. Evol. 4:406-425.

35. Sambrook, J., E. F. Fritsch, and T. Maniatis. 1989. Molecular cloning: a 
laboratory manual, 2nd ed. Cold Spring Harbor Laboratory Press, Cold Spring Harbor, N.Y.

36. Stackebrandt, E., and B. M. Goebel. 1994. A place for DNA-DNA reassociation and $16 \mathrm{~S}$ rRNA sequence analysis in the present species definition in bacteriology. Int. J. Syst. Bacteriol. 44:846-849.

37. Stackebrandt, E., W. Liesack, and D. Witt. 1992. Ribosomal RNA and rDNA sequence analyses. Gene 115:255-260.

38. Stackebrandt, E., D. Witt, C. Kemmerling, R. M. Kroppenstedt, and W. Liesack. 1991. Designation of streptomycete $16 \mathrm{~S}$ and 23S rRNA-based target regions of oligonucleotide probes. Appl. Environ. Microbiol. 57:1468-1477.

39. Swofford, D. L., and G. J. Olsen. 1990. Phylogenetic reconstruction, p. 411-501. In D. Hillis and C. Moritz (ed.), Molecular systematics. Sinauer Associates, Sunderland, Mass.

40. Van Wezel, G. P., E. Vijgenboom, and L. Bosch. 1991. A comparative study of the ribosomal RNA operons of Streptomyces coelicolor A3(2) and sequence analysis of $r n A$. Nucleic Acids Res. 19:4399-4403.

41. Waksman, S. A., and H. A. Lechevalier (ed.) 1953. Guide to the classification and identification of the actinomycetes and their antibiotics. The Williams and Wilkins Co., Baltimore.

42. Waksman, S. A., and R. E. Curtis. 1916. The actinomycetes of the soil. Soil Sci. 1:99-134

43. Waksman, S. A., and A. T. Henrici. 1943. The nomenclature and classifica- tion of the actinomycetes. J. Bacteriol. 46:337-341.

44. Waksman, S. A., and A. T. Henrici. 1948. Family III Streptomycetaceae Waksman and Henrici, p. 929-980. In R. S. Breed, E. G. D. Murray, and P. Hitchens (ed.), Bergey's manual of determinative bacteriology, 6th ed. The Williams and Wilkins Co., Baltimore.

45. Waksman, S. A., W. W. Umbreit, and T. C. Cordon. 1939. Thermophilic actinomycetes and fungi in soils and in composts. Soil Sci. 47:37-61.

46. Wellington, E. M. H., E. Stackebrandt, D. Sanders, J. Wolstrup, and N. O. G. Jorgensen. 1992. Taxonomic status of Kitasatosporia and proposed unification with Streptomyces on the basis of phenotypic and 16S rRNA analysis and emendation of Streptomyces Waksman and Henrici $1943,339^{\mathrm{AL}}$ Int. J. Syst. Bacteriol. 42:156-160.

47. Williams, S. T., M. Goodfellow, and G. Alderson. 1989. Genus Streptomyces Waksman and Henrici $1943,339^{A L}$, p. $2452-2492$. In S. T. Williams, M. E. Sharpe, and J. G. Holt (ed.), Bergey's manual of systematic bacteriology, vol. 4. Williams and Wilkins, Baltimore.

48. Williams, S. T., M. Goodfellow, G. Alderson, E. M. H. Wellington, P. H. A. Sneath, and M. J. Sackin. 1983. Numerical classification of Streptomyces and related genera. J. Gen. Microbiol. 129:1743-1813.

49. Witt, D., and E. Stackebrandt. 1990. Unification of the genera Streptoverticillium and Streptomyces, and amendation of Streptomyces Waksman and Henrici 1943, 339 AL. Syst. Appl. Microbiol. 13:361-371. 